\title{
Kohti vaikuttavampaa ohjausta - ruokasuhteen viitekehys ravitsemuskasvatuksen lähestymistapana
}

\author{
SANNA TALVIA \& SUSANNA ANGLÉ
}

Ruokaan ja syömiseen liittyvällä kasvatuksella on Suomessa ollut pitkään tärkeä rooli osana terveyden edistämistä. Sen varhaisvaiheissa 1800 - ja 1900-lukujen vaihteessa painopiste oli puutostautien ehkäisyssä ja vähävaraisista huolehtimisessa, toisen maailmansodan jälkeen vähitellen pyrkimyksessä ehkäistä yltäkylläisyydestä seuranneita kansansairauksia (1). Ravitsemuskasvatuksen rinnalla on viime vuosina alettu käyttää lasten ja nuorten ravitsemusterveyden edistämiseen liittyvissä asiakirjoissa myös ruokakasvatuksen käsitettä (2-6). Sitä käytettäessä painotukset voivat olla paitsi terveyden edistämisessä, myös esimerkiksi kestävän kehityksen tai ruokakulttuurisen osaamisen lisäämisessä (1).

Ravitsemuskasvatus voidaan määritellä kasvatuksellisena toimintana, jonka päämääränä on edistää yksilöiden ja yhteisöjen ruokaan liittyvien arvojen, asenteiden, tietojen, taitojen ja toimintatapojen kehittymistä terveyttä edistävään suuntaan (7). Se on toimintana laaja-alaista (8). Nupponen on eritellyt ravitsemuskasvatuksen lähestymistapoina yksilöihin kohdistuvan neuvonnan ja ohjauksen, ryhmiin kohdistuvan opetuksen tai valmennuksen ja laajoja yleisöjä tavoittamaan pyrkivän viestinnän (9). Ravitsemuskasvatuksen kentällä toimivien ammattilaisten joukko on siis laaja. Esimerkiksi ravitsemusterapeutit, terveyden- ja sairaanhoitajat, lääkärit, psykologit, personal trainerit, opettajat, nuorisotyöntekijät, sosiaalityöntekijät, valmentajat ja viestinnän ammattilaiset voivat työssään toimia ravitsemuskasvatuksen parissa.

\section{PERINTEISEN RAVITSEMUSKASVATUKSEN KRITIIKKI}

Terveyden edistämiseen pyrkivä ravitsemuskasvatus on herättänyt kritiikkiä eri syistä. Osa kritiikistä on noussut ravitsemus- ja terveystietei- den, osa yhteiskunta- ja humanististen tieteiden kentältä. Toistuvia kritiikin kohteita ovat olleet ravitsemuskasvatuksen tieto- ja yksilökeskeisyys. Myös terveellisen syömisen moraalisesta luonteesta on tehty huomioita.

Muiden muassa pohjoismaiset kriittisen ravitsemustieteen edustajat ovat arvostelleet perinteistä tapaa hahmottaa syömiskäyttäytymiseen vaikuttaminen yksilön valistamisena ja vastuuttamisena (10). Heidän mukaansa ravitsemusinterventiot pohjautuvat edelleen pitkälti tiedon jakamiselle ja markkinointistrategioille, vaikka ihmisten valistaminen "oikealla tiedolla" ei ole osoittautunut riittäväksi edellytykseksi käyttäytymisen muutokselle. Ravitsemussuositusten tunteminen ei automaattisesti johda ruokatottumusten terveellisyyteen (11). Yleisesti ottaen näyttää siltä, että paremmalla ravitsemustietämyksellä olisi yhteys terveellisempiin ruokatottumuksiin, mutta yhteys ei ole kovin vahva (12). Tämä ei ole yllättävää, selittäväthän syömiseen liittyviä valintoja ja käyttäytymistä lopulta lukuisat biopsykososiaaliset, kulttuuriset ja yhteiskunnalliset tekijät $(8,13)$.

Kriittistä huomiota on kiinnitetty myös ajatukseen "vääränlaisesta" syömisestä ja siihen linkittyvään kehon koon ja muodon stigmatisointiin (10). Puheeseemme ruoasta ja syömisestä liittyy helposti moraalinen pohjavire, joka leimaa ruoan terveelliseksi ja hyväksi tai epäterveelliseksi ja huonoksi (14). Tämä voi vaikuttaa kokemuksiimme ja tunteisiimme paitsi ruoasta myös meistä itsestämme. Laadullisessa katsausartikkelissaan Bisogni ja kumppanit toteavat, että maallikkojen tulkintoihin terveellisestä syömisestä liittyy usein kuvaus ihanteellisesta syömisestä, joka latautuu moraalisesti hyvänä ja oikeana, ja josta poikkeaminen herättää syyllisyyden tuntei- 
ta (15). Saman havaitsivat Delaney ja McCarthy tutkiessaan irlantilaisten ikääntyneiden kokemuksia ja käsityksiä omasta syömisestään (16). Tutkijat pohtivat, miten terveellinen syöminen voi tuottaa vahvuuden ja tyytyväisyyden tunteita niille, jotka onnistuvat syömään "oikein", mutta syyllisyyttä ja häpeää niille, jotka tässä epäonnistuvat ja jäävät uhreiksi terveellisen syömisen kilvoittelussa. Osassa ihmisiä ruokaan liitetyt moraaliset lataukset herättävät ärsyyntynyttä kapinamieltä $(16,17)$. Tätä voi kuvata myös esim. ravitsemussuositusten nimittäminen "terveysterrorismiksi”. Tällöin ravitsemuskasvatus kääntyy tarkoituksensa vastaiseksi.

Myös lasten ja nuorten ruokailua ja ruokakasvatusta kouluympäristöissä tarkastelleet tutkijat ovat kritisoineet ruoan ja syömisen hahmottuvan tutkimuksissa usein kapea-alaisiksi terveys- ja ravintoainekysymyksiksi $(18,19)$. Robertson ja Scheidler-Benns havaitsivat kanadalaisia opetussuunnitelmia tutkiessaan terveellisen syömisen jäsentyvän niissä ennen kaikkea yksilön tekeminä "oikeina" valintoina ja vastuuna, ei niinkään monimutkaisena prosessina, jossa myös ympäristötekijöillä on ratkaiseva merkitys (20). Ruokateeman käsittelyä australialaisissa koululuokissa tutkineet Leahy ja Wright nostavat esiin ruoan ja syömisen rakentuvan opetuksessa suppeasti tietynlaisena hyväksyttävänä kehona ja syömisen tapana, joihin liittyy kyseenalaistamaton ajatus vastuullisesta kansalaisesta (21). Pelkästään yksilöä vastuuttamalla unohdetaan, että käyttäytymisen lähtökohdat eivät synny vain yksilössä itsessään, vaan monimutkaisen sosiaalisten, kulttuuristen, infrastruktuurillisten ja taloudellisten reunaehtojen tuloksena (10).

\section{EHDOTUS SYÖMISEN JÄSENTÄMISESTÄ RUOKASUHTEENA}

Vaikka ravitsemuskasvatusta kohtaan on viime vuosina esitetty laajalti kritiikkiä, ovat varsinaiset uudet teoreettiset tai konkreettiset avaukset lähinnä loistaneet poissaolollaan. Itse lähdimme kehittelemään ruokasuhteen viitekehystä uutena ravitsemuskasvatuksen jäsennyksenä, joka pyrkii huomioimaan myös edellä kuvattua ravitsemuskasvatukseen kohdistunutta kritiikkiä.

Ehdotamme ruokasuhde -viitekehystä erityisesti ruoka- ja ravitsemuskasvatusta tekevien ammattilaisten tueksi ja työkaluksi: lisäämään ymmärrystä syömisestä monitasoisena ilmiönä ja auttamaan ravitsemuskasvatuksellisen työn suunnittelussa ja toteuttamisessa entistä kokonaisvaltaisemmalla tavalla. Sitä voitaneen hyödyntää myös osana syömishäiriöiden ja lihavuuden hoitoa. Toivomme, että ruokasuhde auttaa ammattilaista hahmottamaan, miksi pelkkä tiedon jakaminen ei riitä muuttamaan syömiskäyttäytymistä. Viitekehys pyrkii tekemään näkyväksi ja toisaalta ottamaan myös tarvittavaa etäisyyttä terveelliseen syömiseen liittyvään moraaliseen jännitteeseen, jossa yksittäiset valinnat määrittyvät kyseenalaistamattomasti oikeiksi tai vääriksi, hyviksi tai huonoiksi. Kysymyksellä "Millainen on suhteeni ruokaan?" saadaan kuvailevia vastauksia, joita ei ole tarkoitus arvottaa.

\section{RAVITSEMUSKASVATUS POHJAUTUU KÄSITYKSELLE IHMISESTÄ JA OPPIMISESTA}

Olipa kyse yksilöohjauksesta, ryhmäopetuksesta tai laajemman yhteisön ohjauksesta, pyrkimys vaikuttaa muihin perustuu aina jollekin ihmiskäsitykselle, olettamuksille ihmisen perusolemuksesta ja muuttumisesta. Toimimattomaksi osoittautunut tiedon ja neuvojen jakamiselle perustuva ravitsemuskasvatus on pohjautunut ihmis- ja oppimiskäsityksille, jotka ovat vanhentuneita ja pulmallisia. Ihminen ei ole ainoastaan rationaalinen tai mekanistinen olento, joka oppii ja muuttuu vain auktoriteetin ulkoapäin (tai paremminkin ylhäältäpäin) antamia tietoja ja ohjeita vastaanottamalla.

Kehittelemämme ruokasuhde -viitekehys pohjautuu holistiselle ihmiskäsitykselle. Filosofi Lauri Rauhalan kehittämää ihmiskäsitystä sovelletaan laajasti ihmistieteissä ja vuorovaikutustyössä (22). Siinä ihmisyys nähdään perustaltaan kolmijakoisena: kehollisena, tajunnallisena ja situationaalisena. Ulottuvuudet toteutuvat yhteispelissä ja mahdollistavat toinen toisensa. Kehollisuus viittaa aineellisiin ja orgaanisiin tapahtumiin ja biologiseen olemassaoloomme. Tajunnallisuus tarkoittaa inhimillisen kokemisen kokonaisuutta, kaikkea mistä voimme tulla tietoiseksi, ja taipumusta antaa asioille merkityksiä. Situationaalisuus on ihmisen kietoutuneisuutta todellisuuteen oman elämäntilanteensa kautta; kaikki se, mihin kehollisuus ja tajunnallisuus ovat suhteessa (esim. ulkoinen todellisuus, toiset ihmiset). Kolmen ulottuvuuden dynamiikan seurauksena on ainutlaatuinen ja vertaamaton yksilöllinen kokemisen tapa; yksilön suhde todellisuuteen on aina uniikki. Oppiminen nähdään merkityssuh- 
teiden muodostumisena. Omaa olemassaoloaan merkitysten avulla ymmärtäen ihminen voi ohjata elämäänsä.

Ruokasuhde -viitekehys pohjautuu holistisille näkemyksille ihmisen ainutkertaisesta yksilöllisyydestä, oppimisesta merkityssuhteiden luomisena, sekä ihmisen omaehtoisen muutoksen mahdollisuudesta. Ruokasuhde on koko elämän ajan kertyneiden, ruokaan ja syömiseen liittyvien yksilöllisten kokemusten, sekä yksilön näille kokemuksilleen antamien tulkintojen ja merkitysten muodostama ainutlaatuinen kokonaisuus, joka elää tilanteen ja kontekstin mukaan. Esimerkiksi nälän tunteen keholliset merkit lienevät yleisinhimilliset, mutta nälän tunnistaminen merkitsee eri asioita sille, joka elää yltäkylläisyydessä, sille, jolla ei ole rahaa ruokaan, sekä sille, joka on sairauden vuoksi kadottanut ruokahalun ja kyvyn tuntea nälkää. Näin ollen ruokasuhteen tarkasteleminen -saati siihen vaikuttaminen- ei onnistu ulkoapäin, vaan ammattilaiselle se tulee näkyväksi ainoastaan dialogissa ohjattavan kanssa.

\section{RUOKASUHDE -VIITEKEHYKSEN MUITA KESKEISIÄ LÄHTÖKOHTIA}

Ruokasuhde -viitekehyksen lähtökohtana on ajatus syömisen moniulotteisuudesta ja kietoutumisesta osaksi ihmisen koko elämää - niin fyysistä, psyykkistä kuin sosiaalistakin. Viitekehys kytkeytyy myös tapaan tarkastella syömistä uteliaasti, rohkeasti, rehellisesti, hyväksyvästi ja armollisesti, oli kyseessä sitten oma tai toisen syöminen.

Viitekehystä luotaessa on tutustuttu ympäristökasvatuksen kentällä hyödynnettyyn luontosuhteen käsitteeseen (23) ja liikunnan edistämiseen linkittyvään liikuntasuhteen käsitteeseen $(24,25)$. Kehitystyössä on hyödynnetty lisäksi olemassa olevaa, syömiskäyttäytymistä kuvaavaa teoriakirjallisuutta, kuten ruoanvalinnan prosessimallia (13).

Olemme saaneet vaikutteita myös terveyskäyttäytymistutkimuksen piirissä tällä hetkellä näkyvästi esillä olevasta itsemääräämisen teoriasta (26). Teorian mukaan oman toiminnan pysyvä muuttaminen edellyttää ns. sisäistä motivaatiota. Se motivoituu (esim. parempaan hyvinvointinsa ylläpitämiseen), joka kokee saavansa itse päättää, kykenevänsä, ja tulevansa hyväksytyksi. Samoin olemme hyödyntäneet itsemyötätunnon teoriaa (27). Itsemyötätunto rakentuu kolmesta keskeisestä tavasta suhtautua itseen: lempeästä ystävällisyydestä itseä kohtaan tuomitsemisen sijaan, ymmärryksestä kaikkia ihmisiä yhdistävästä epätäydellisyydestä sekä tietoisesta läsnäolosta, asioiden kohtaamisesta niitä vähättelemättä mutta myöskään suurentelematta.

Paradoksaalisesti hyväksyvän utelias tapa tarkastella omaa toimintaa on parempi pohja muutoksenkin mahdollisuudelle, kuin kokemus arvioituna tai painostettuna olemisesta. Esimerkiksi yksi vakiintuneimmista ja tutkituimmista terveyskäyttäytymisen edistämisen menetelmistä, motivoiva haastattelu, perustuu tälle tuomitsemattomuuden ja neutraalisuuden periaatteelle: ammattilainen välttää arvottamista ja neuvomista, ja antaa ohjattavan itse löytää halun muuttaa käyttäytymistään (28).

Näemme, että terveellisen syömisen edistämisessä erityisen olennaista onkin vuorovaikutus ja kohtaamisen tapa. Ajattelemme, että ohjauksellisissa kohtaamisissa kyse ei niinkään ole siitä, mitä saamme siirrettyä kohderyhmälle, vaan siitä, mitä ihmisissä herää kohtaamisen ansiosta. Olennaista on myös rehellinen, mutta samalla myötätuntoinen oman syömisen tarkastelu ja siten tapahtuva tietoisuuden lisääntyminen. Parhaimmillaan tämä voi merkitä muuttamisen ja muuttumisen pakosta irrottautumista ja luottamista hyväksymisen voimaan. Painostuksen ja syyllisyyden tunteesta vapaa on vapaa muuttumaan omilla ehdoillaan.

\section{RUOKASUHTEEN OSA-ALUEET}

Ruokasuhde-viitekehys muodostuu viidestä toisiinsa kietoutuvasta näkökulmasta (Kuvio). Näkökulmat eivät ole tarkkarajaisesti toisistaan erotettavissa, vaan ne ovat tiiviisti vuorovaikutuksessa. Käyttäytymisen näkökulma tarkastelee ruokaan ja syömiseen liittyvää konkreettista tekemistä: mitä, milloin, missä ja kenen kanssa syömme, ja niin edelleen. Ajatusten näkökulma tuo esiin ruokaan ja syömiseen liittyvät ajatuksemme: millaisia ruokaan liittyviä uskomuksia meillä on, miten luokittelemme ruokia, millaisia kognitiivisia käsikirjoituksia (skriptejä) meillä on ruokailutilanteiden kulkuun liittyen. Kolmas, erittäin tärkeä näkökulma ovat tunteet: millaisia tunteita erilaiset ruuat tai syömistilanteet meissä herättävät, miten tunteet saavat meitä syömään tai olemaan syömättä tai millaisia tunteita tietyn ruuan syömisestä herää. Kehon ja aistien näkökulmassa keskiössä on oma henkilökohtainen tapamme 


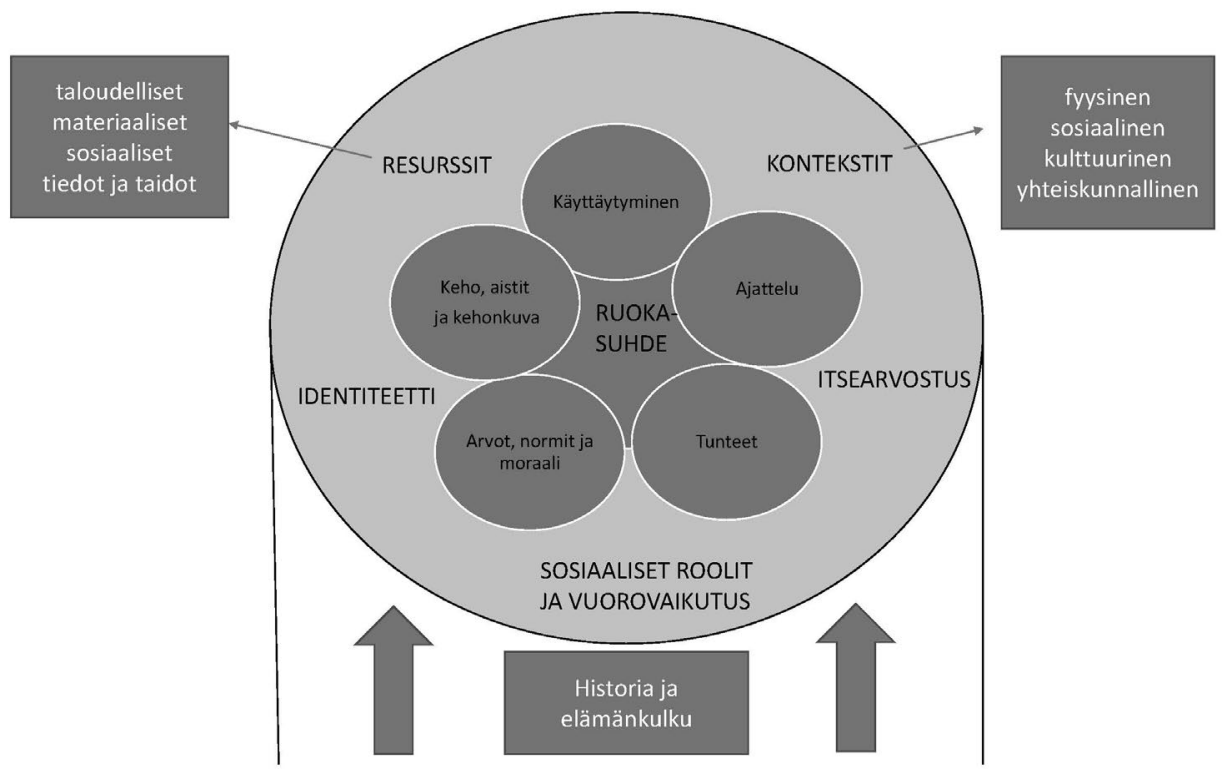

aistia ruokaa ja tuntea se kehossamme. Keskeistä on myös kehonkuvan ja syömisen välinen yhteys. Arvojen ja normien näkökulma nostaa esiin arvot, eli asiat, jotka meille ovat syömisessä tärkeitä ja joita haluamme siinä toteuttaa, sekä normit eli käsityksemme siitä, miten meidän tulisi itsemme tai muiden mielestä syödä. Normeista muodostuu syömisen moraalinen ulottuvuus. Syömisen moraalista latausta ei kielletä, vaan ennemminkin tehdään se näkyväksi, jolloin mahdollisten haitallisten moraalisten jännitteiden purkaminen mahdollistuu.

Sosiaaliset roolit ja vuorovaikutus, kontekstit ja resurssit ovat mukana ruokasuhde-viitekehyksessä kuvaamassa sitä, miten vuorovaikutustekijät ympäristön kanssa vaikuttavat suhteeseemme ruokaan. Sillä, millainen rooli meillä on suhteessa muihin ihmisiin ja millaisessa ympäristössä olemme, on vaikutuksensa kaikkiin ruokasuhteen ulottuvuuksin. Voimme toimia, ajatella, tuntea ja kokea eri tavoin ja tavoitella erilaisia asioita esimerkiksi vanhempana kodin ruokailutilanteessa, oppilaana vertaisten seurassa kouluruokailussa, työkaverina työpaikkaruokalan lounaalla tai seurustelukumppanina intiimillä illallisella. Fyysisen ja sosiaalisen ympäristön lisäksi ruokasuhde on vuorovaikutuksessa laajemman kulttuurisen ja yhteiskunnallisen kontekstin kanssa. Myös resurssit määrittävät suhdettamme ruokaan. Resursseja voivat olla niin taloudelliset, materiaaliset, sosiaaliset, tiedolliset kuin taidollisetkin re- surssit. Ruokasuhde toteutuu eri tavoin riippuen esimerkiksi siitä, kuinka paljon meillä on varallisuutta, ruuanvalmistuksen välineitä, tiloja tai aikaa käytössämme, saammeko tarvittaessa apua ruoka-askareisiin muilta tai onko meillä ruokaan liittyviä tietoja tai taitoja käytössämme. Edellisten lisäksi ruokasuhteemme on tiivistii yhteydessä myös esim. identiteettiimme ja itsearvostukseemme. Ruokavalintojemme tai vaikkapa jonkin ruokavalion noudattamisen kautta viestimme ja otamme kantaa siihen, keitä olemme. Myönteinen minäkuva ja kiinnostus omaa hyvinvointia kohtaan todennäköisesti heijastuu syömiskäyttäytymiseen eri tavalla kuin alhainen itsearvostus.

Ruokasuhde-viitekehykseen liittyy vahvasti ajatus ruokasuhteen kehittymisestä koko elämän ajan. Sillä, miten tänään suhtaudumme ruokaan, voi olla juurensa kaukana menneisyydessä. Erilaiset ruokaan ja syömiseen liittyvät kokemukset muokkaavat ruokasuhdettamme jatkuvasti. Oman ruokasuhde-elämäntarinan avaaminen voi auttaa meitä ymmärtämään paremmin sitä, miksi suhtaudumme ruokaan ja syömiseen niin kuin suhtaudumme.

\section{VIITEKEHYKSEN HYÖDYNTÄMINEN TULEVAISUUDESSA}

Toistaiseksi ravitsemuskasvatuksen kentällä on lähinnä oltu kiinnostuneita "kohderyhmän" ruokakäyttäytymisestä. Ruokasuhteen viitekehys nostaa kiinnostuksen kohteeksi myös ammattilaisen oman ruokasuhteen sekä ammattilaisen ja oh- 
jattavan välisen vuorovaikutussuhteen. Katsomme, että ammattilaisen olisi hyvä olla tietoinen oman ruokasuhteensa eri puolista ja siitä, miten oma ruokasuhde vaikuttaa tapaan tehdä ravitsemuskasvatustyötä.

Toivomme ruokasuhteen toimivan kokonaisvaltaisena näkökulmana syömiseen ja sen äärellä työskentelyyn. Ruokasuhde-viitekehys ei ole varsinainen teoria, joka selittäisi käyttäytymistä tarkasti, tai olisi suoraan operationalisoitavissa mitattaviksi muuttujiksi. Kyseessä on enemmänkin ravitsemuskasvatuksen suunnittelua ja toteuttamista ja ravitsemuskasvatuksen ammattilaisen ammatillista kehittymistä palvelemaan ajateltu työkalu. Kuitenkin esimerkiksi subjektiivinen kokemus omasta ruokasuhteesta voi olla mahdollista ja mielekästä kääntää myös mittariksi. Samoin viitekehyksen näkökulmat voivat olla hyödynnettävissä jatkossa laajemminkin esimerkiksi tutkimuksessa tai terveys-, ravitsemus- ja koulutuspoliittisessa työskentelyssä laadittaessa muun muassa uusia ravitsemussuosituksia tai opetussuunnitelmia. Olisi myös kiinnostavaa tutkia ruokasuhde-viitekehyksen yhteyksiä muihin ruoka- ja ravitsemuskasvatuksen käsitteisiin ja metodisiin välineisiin, kuten Syömisen taito - lähestymistapaan (29) tai Ruokatajuun (1).

Ruokasuhdetta voi tässä vaiheessa pitää vielä kehittyvänä, luonnosvaiheessa olevana viitekehyksenä. Tällä hetkellä kehitämme sitä edelleen ja testaamme viitekehyksen käytännön sovellettavuutta Sosiaali- ja terveysministeriön terveyden edistämisen määrärahalla rahoitetussa Kehonkuva hyvinvoinnin perustana (KEHUVA) -hankkeessa. Vuosien 2017-2019 aikana toteutettavassa hankkeessa kehitetään muun muassa ruokasuhteeseen, kehonkuvaan ja syömisen taitoon liittyviä käytännön menetelmiä Itä-Suomen, Helsingin ja Tampereen yliopistojen sekä Helsingin Diakonissalaitoksen Vamos -palveluiden yhteistyönä.

\section{LÄHTEET}

(1) Janhonen K, Mäkelä J, Palojoki P. Perusopetuksen ruokakasvatus ravintotiedosta ruokatajuun. Kirjassa: Janhonen-Abruquah H, Palojoki P. (toim.) Luova ja vastuullinen kotitalousopetus. Helsinki: Helsingin yliopisto, 2015. Opettajankoulutuslaitos; 2015, 107-120.

(2) Valtion ravitsemusneuvottelukunta. Syödään yhdessä - Ruokasuositukset lapsiperheille. Terveyden ja hyvinvoinnin laitos, 2016. Luettu 26.7.2018. http://urn.fi/ URN:ISBN:978-952-302-599-8

(3) Valtion ravitsemusneuvottelukunta. Syödään ja opitaan yhdessä - Kouluruokailusuositus. Terveyden ja hyvinvoinnin laitos, 2017. Luettu 26.7.2018. http://urn.fi/ URN:ISBN:978-952-302-791-6

(4) Valtion ravitsemusneuvottelukunta. Terveyttä ja iloa ruoasta - Varhaiskasvatuksen ruokailusuositus. Terveyden ja hyvinvoinnin laitos, 2018. Luettu 26.7.2018. http://urn.fi/ URN:ISBN:978-952-302-992-7

(5) Opetushallitus. Perusopetuksen opetussuunnitelman perusteet. Opetushallituksen määräykset ja ohjeet 2014:96. Helsinki: Opetushallitus; 2014.

(6) Opetushallitus. Varhaiskasvatussuunnitelman perusteet. Opetushallituksen määräykset ja ohjeet 2016:17. Helsinki: Opetushallitus; 2016.

(7) Lakka T, Talvia S, Sääkslahti, Haapala E. Fyysinen aktiivisuus ja ravitsemus lasten terveyden edistämisessä - tavoitteena lihavuuden, tyypin 2 diabeteksen ja valtimotautien ehkäisy. Kirjassa: Pietilä A-M,

(8) Cuomen yliopiston julkaisusarja. Painossa research, theory, and practice. 2. painos. Sudbury: Jones and Bartlett Publishers; 2011.

(9) Nupponen R. Ravitsemuskasvatus terveyden edistämisessä. Kirjassa: Fogelholm M. (toim.) Ratkaisuja ravitsemukseen. Ravitsemuskasvatus ja elämänkaari. Helsinki: Palmenia-kustannus; 2001, 15-32.

(10) Neuman N, Lövestam E. Toward a critical dietetics in the Nordic countries. Journal of Critical Dietetics 2018;4:5-13.

(11) Haack SA, Byker CJ. Recent population adherence to and knowledge of United States federal nutrition guides, 1992-2013: a systematic review. Nutr Rev 2014;72:613-626. https://doi.org/10.1111/nure.12140

(12) Spronk I, Kullen C, Burdon C, ym. Relationship between nutrition knowledge and dietary intake. Br J Nutr 2014;111:1713-26. https://doi.org/10.1017/S0007114514000087

(13) Sobal J, Bisogni CA. Constructing foof choice decisions. Ann Behav Med 2009;38(Suppl 1) S37-46. https://doi.org/10.1007/s12160-009-9124-5

(14) Joy P, Jackson R, Numer MA. Mythical battle: 'good' foods versus 'bad' foods. Journal of Critical Dietetics 2018;4:2-4.

(15) Bisogni CA, Jastran M, Seligson M, ym. How people interpret healthy eating: contributions 
of qualitative research. J Nutr Educ Behav 2012;44:282-301.

https://doi.org/10.1016/j.jneb.2011.11.009

(16) Delaney M, McCarthy MB. Saints, sinners and non-believers: the moral space of food. A qualitative exploration of beliefs and perspectives on healthy eating of Irish adults aged 50-70. Appetite 2014;73:105-13. https://doi.org/10.1016/j.appet.2013.10.017

(17) O’Key V, Hugh-Jones S. II don't need anybody to tell me what I should be doing. 'A discursive analysis of maternal accounts of (mis)trust of healthy eating information. Appetite 2010;54:524-532. https://doi.org/10.1016/j.appet.2010.02.007

(20) Priyadharshini E, Carrington V. Editorial Food, Youth and Education. Cambridge Journal of Education 2016;46:153-155. https://doi.org/10.1080/030576 4X.2016.1161210

(19) Rückenstein M. Kouluruokailun vaikuttajat. Kansalaiskasvatuksesta kulutuskulttuuriin. Kirjassa: Pekkarinen E, Vehkalahti K, Myllyniemi S. (toim.) Lapset ja nuoret instituutioiden kehyksissä. Nuorten elinolot -vuosikirja 2012. Helsinki: Nuorisotutkimusseura;156-169.

(20) Robertson L, Scheidler-Benns J. Using a wider lens to shift the discourse on food in Canadian curriculum policies. Cambridge Journal of Education 2016;46:157-175.

https://doi.org/10.1080/030576 4X.2015.1091440

(21) Leahy D, Wright J. Governing food choices: a critical analysis of school food pedagogies and young people's responses in contemporary times. Cambridge Journal of Education 2016;46: 233-246. https://doi.org/10.1080/0305764X.2015.1118440

(22) Rauhala L. Ihmiskäsitys ihmistyössä. Helsinki: Yliopistopaino; 2005.

(23) Cantell, H. Lapsuus ja nuoruus ympäristösuhteen perustana. Kirjassa: Niemelä J, Furman E, Halkka A, Hallanaro E-L, Sorvari S. (toim.) Ihminen ja ympäristö. Helsinki: Gaudeamus, 2011, 332-338.
(24) Rovio E, Saaranen-Kauppinen A, Pyykkönen T. Liikuntakynnyksen yli - ohjelmista ihmisen kohtaamiseen. Impulssi numero 28. Helsinki: Liikuntatieteellinen seura; 2014.

(25) Koski P. 2004. Liikuntasuhde - liikunnan kohtaaminen kulttuurisesti rakentuvana sosiaalisena maailmana. Kirjassa: Ilmanen K. (toim.) Pelit ja kentät - kirjoituksia liikunnasta ja urheilusta. Liikunnan sosiaalitieteiden laitos, tutkimuksia 3/2004. Jyväskylä: Jyväskylän yliopisto; 2004,189-208.

(26) Ryan RM, Deci EL. Self-Determination Theory and the Facilitation of Intrinsic Motivation, Social Development, and Well-Being. Am Psychol 2000;55:68-78.

(27) Neff K. The Role of self-compassion in development: a healthier way to relate to oneself. Human Development 2009;52: 211-214. https://doi.org/10.1159/000215071

(28) Miller WR, Rollnick S. Motivational interviewing. Helping people change. 3. painos. New York: The Guilford Press; 2013.

(29) Satter E. Eating competence: nutrition education with the Satter Eating Competence Model. J Nutr Educ Behav 2007;39(5 Suppl):S189-94. https://doi.org/10.1016/j.jneb.2007.04.177

\section{Sanna TAlvia \\ FT, ETM, KM \\ Tutkijatohtori, hankekoordinaattori \\ Itä-Suomen yliopisto}

Kansanterveystieteen ja kliinisen ravitsemustieteen $y k s i k k \ddot{o}$

\section{Susanna Anglé}

PsT

Tampereen yliopisto

Yhteiskuntatieteiden tiedekunta 